\title{
Effect of different planting geometry and herbicides for controlling the weeds in direct seeded rice
}

\author{
Neeshu Joshi*, V. Pratap Singh and V. C. Dhyani \\ -263145 (Uttarakhand), INDIA \\ *Corresponding author. E-mail: neeshu.joshi@gmail.com \\ Received: January 28, 2016; Revised received: September 2, 2016; Accepted: November 25, 2016
}

Department of Agronomy College of Agriculture, G.B. Pant University Agriculture \& Technology, Pantnagar

\begin{abstract}
The efficacy of selected herbicides along with the planting geometry for weed control in direct seeded rice was evaluated under tropical conditions of Pantnagar during rainy season of 2013. Pendimethalin ( $1 \mathrm{~kg}$ active ingredient (a.i.) ha ${ }^{-1} 3$ days after sowing) + bispyribac-Na $\left(25 \mathrm{~g}\right.$ a.i. ha ${ }^{-1} 28$ days after sowing) + one hand weeding at 45 days after sowing and bispyribac-Na $\left(25 \mathrm{~g}\right.$ a. i. ha ${ }^{-1} 28$ days after sowing) + one hand weeding at 45 days after sowing had a mean grain yield of 47.95 and 37.68 while continuous drilling at $20 \mathrm{~cm}$ and $20 \times 10 \mathrm{~cm}$ had a mean grain yield 34.72 and $34.14 \mathrm{qha}^{-1}$, respectively which is significantly superior than wider $(25 \times 25 \mathrm{~cm})$ spacing. Wider spacing $(25 \times 25 \mathrm{~cm})$ among planting geometry and weedy check among the weed control treatments resulted in higher uptake of nitrogen. Among the spacing, continuous drilling at $20 \mathrm{~cm}$ and Pendimethalin $\left(1 \mathrm{~kg}\right.$ a.i. ha $\left.{ }^{-1}\right)+$ bis- $^{-}$ pyribac-Na $\left(25 \mathrm{~g}\right.$ a.i. ha $\left.{ }^{-1}\right)+$ one hand weeding at 45 days after sowing among weed control practices proved most profitable with net returns of ₹ $40576 \mathrm{ha}^{-1}$ and ₹ $40633 \mathrm{ha}^{-1}$ and benefit:cost ratio of 1.7 and 1.8, respectively. It was revealed that all the weed control treatments were superior to weedy conditions.
\end{abstract}

Keywords: Direct seeded rice, Herbicides, Net returns, Planting geometry, Weed control efficiency

\section{INTRODUCTION}

Weed infestation in direct seeded rice (DSR) fields remains the single largest constraint limiting their productivity. A DSR crop generally lacks a "head start" over weeds due to dry tillage, absence of flooding and alternate wetting and drying conditions making it particularly vulnerable to weed competition during early part of its growth (Rao et al., 2007). As the weeds and rice emerge simultaneously in DSR, the proper time and method of weed control remains a complex phenomenon (Khaliq and Matloob, 2011). Hence study was undertaken to determine the efficacy of alone or combination of herbicides with hand weeding along with different planting geometry for effective control of weeds in direct seeded rice.

\section{MATERIALS AND METHODS}

The field experiments were conducted during the wet season of 2013 at Crop Research Centre of GBPUAT, Pantnagar. The $\mathrm{pH}$ (Jackson, 1973), organic carbon (Black, 1965) and available N (Subbiah and Asija, 1956), P (Olsen et al., 1954), K (Jackson, 1973) content were $7.3,0.86 \%, 226.2,22.8$ and $145.4 \mathrm{~kg} \mathrm{ha}^{-1}$, respectively. The treatments comprised of planting geometry (continuous drilling at $20 \mathrm{~cm}, 20 \times 10 \mathrm{~cm}$ and $25 \times 25 \mathrm{~cm}$ ) in the main plots and pendimethalin at $1 \mathrm{~kg}$ $\mathrm{ha}^{-1}, 3$ days after sowing (DAS) + hand weeding at 30 DAS; bispyribac- $\mathrm{Na}$ at $25 \mathrm{~g} \mathrm{ha}^{-1}, 30 \mathrm{DAS}+$ hand weeding at $45 \mathrm{DAS}$; pendimethalin at $1 \mathrm{~kg} \mathrm{ha}^{-1}, 3 \mathrm{DAS}$ + bispyribac- $\mathrm{Na}$ at $25 \mathrm{~g} \mathrm{ha}^{-1}, 30 \mathrm{DAS}+$ hand weeding at 45 DAS and weedy check among weed control treatments in sub-plots in a factorial randomized block design with four replications. Direct seeding of Pant dhan -12 was done in field in three different spacings at the seed rate of 40, 26 and $8.5 \mathrm{~kg} \mathrm{ha}^{-1}$. Crop was supplied with a fertility dose of 120,60 and $40 \mathrm{~kg} \mathrm{~N}, \mathrm{P}_{2} \mathrm{O}_{5}$ and $\mathrm{K}_{2} \mathrm{O}$ ha ${ }^{-1}$, respectively. Full dose of $\mathrm{P}_{2} \mathrm{O}_{5}$ and $\mathrm{K}_{2} \mathrm{O}$ and one third of $\mathrm{N}$ were applied as basal and rest two-third was top dressed in two equal splits, one at active tillering and other at panicle initiation stage. Full dose of $\mathrm{P}_{2} \mathrm{O}_{5}$ and $\mathrm{K}_{2} \mathrm{O}$ and half of $\mathrm{N}$ was applied through NPK mixture and rest half through urea. Weed samples were collected by using a quadrate $(0.5 \mathrm{~m} \times 0.5 \mathrm{~m})$ randomly at two places inside a plot and then converted to per square meter. Crop samples were collected from one meter row length and then converted to per square meter. Nitrogen use efficiency (NUE) was computed by using the formula ( $\mathrm{kg}$ grains per $\mathrm{kg}$ nitrogen applied) $\mathrm{X} 100$, whereas weed control efficiency was computed on population basis.

\section{RESULTS AND DISCUSSION}

The most dominant weed species found in the weedy plots were Echinochloa crussgalli, E. colona, Leptochloa chinensis, Caesulia axillaris, Ammania spp., Cyperus spp. It was found that all the weed control treat- 
Table 1. Grain yield, yield attributes, nitrogen uptake, N-use efficiency and economics in direct seeded rice under different weed control treatments.

\begin{tabular}{|c|c|c|c|c|c|c|c|c|}
\hline Treatments & $\begin{array}{c}\text { Panicles } \\
\mathbf{m}^{-2}\end{array}$ & $\begin{array}{c}\text { Grains } \\
\text { panicle }^{-1}\end{array}$ & $\begin{array}{c}\text { Grain } \\
\text { yield(q ha } \\
\text { 1) }\end{array}$ & \multicolumn{2}{|c|}{$\begin{array}{c}\text { N Uptake weeds (kg } \\
\left.\text { ha }^{-1}\right) \\
\text { Crop Weeds }\end{array}$} & $\begin{array}{l}\text { N-use effi- } \\
\text { ciency (kg } \\
\text { grain } \mathrm{kg}^{-1} \mathbf{N} \\
\text { applied) } \\
\end{array}$ & $\begin{array}{c}\text { Net re- } \\
\text { turns (Rs } \\
\left.\text { ha }^{-1}\right)\end{array}$ & $\begin{array}{c}\text { Benefit: } \\
\text { cost } \\
\text { ratio }\end{array}$ \\
\hline \multicolumn{9}{|c|}{ Planting geometry (spacing in cm) } \\
\hline $\begin{array}{l}\text { Conti. drilling at } 20 \\
\mathrm{~cm}\end{array}$ & 204.0 & 213.3 & 34.72 & 111.4 & 12.5 & 73.3 & 40576 & 1.7 \\
\hline $20 \times 10$ & 191.8 & 204.0 & 34.14 & 103.5 & 13.1 & 71.3 & 38215 & 1.6 \\
\hline $25 \times 25$ & 152.7 & 211.0 & 28.99 & 99.3 & 13.8 & 67.6 & 32048 & 1.5 \\
\hline $\mathrm{SEm} \pm$ & 8.4 & 2.9 & 1.40 & 2.3 & 0.3 & 0.6 & - & - \\
\hline C.D. at $5 \%$ & 24.3 & NS & 4.04 & 6.6 & NS & 1.9 & - & - \\
\hline \multicolumn{9}{|c|}{ Weed control practices } \\
\hline $\begin{array}{l}\text { Pendi fb 1HW } \\
\text { (30DAS) }\end{array}$ & 196.3 & 216.0 & 36.25 & 125.1 & 10.6 & 55.8 & 30498 & 1.4 \\
\hline $\begin{array}{l}\text { Bispyri fb } 1 \mathrm{HW} \\
\text { (45DAS) }\end{array}$ & 205.9 & 218.0 & 37.68 & 112.9 & 11.5 & 69.0 & 32135 & 1.5 \\
\hline $\begin{array}{l}\text { Pendi fb Bispyri } \\
\text { fb } 1 \mathrm{HW}(45 \mathrm{DAS})\end{array}$ & 238.1 & 227.0 & 47.95 & 97.0 & 6.0 & 76.4 & 40633 & 1.8 \\
\hline Weedy check & 91.1 & 176.1 & 8.58 & 83.8 & 26.6 & 81.7 & 2073 & 0.11 \\
\hline $\mathrm{SEm} \pm$ & 9.7 & 3.4 & 1.62 & 2.6 & 0.4 & 0.7 & - & - \\
\hline C.D. at $5 \%$ & 28.1 & 9.8 & 4.66 & 7.7 & 1.2 & 2.2 & - & - \\
\hline
\end{tabular}

Original values are given in parenthesis; Pendi: Pendimethalin, Bispyri:Bispyribac-Na, HW: Hand weeding

Table 2. Weed count, weed dry matter and weed control efficiency in direct seeded rice under different weed control treatments at harvest stage.

\begin{tabular}{|c|c|c|c|}
\hline Treatments & Total weed population $\left(\right.$ no $\left.^{-2}\right)$ & Total weed dry matter $\left(\mathrm{g} \mathrm{m}^{2}\right)$ & $\begin{array}{c}\text { Weed control efficiency } \\
(\%)\end{array}$ \\
\hline \multicolumn{4}{|c|}{ Planting geometry(spacing in cm) } \\
\hline Conti. Drilling at $20 \mathrm{~cm}$ & $5.5(35.5)$ & $6.8(59.0)$ & 66.3 \\
\hline $20 \times 10$ & $5.8(42.8)$ & $7.6(65.5)$ & 65.5 \\
\hline $25 \times 25$ & $5.9(43.2)$ & $7.9(70.0)$ & 63.8 \\
\hline $\mathrm{SEm} \pm$ & 0.07 & 0.08 & 1.9 \\
\hline C.D. at $5 \%$ & 0.2 & 0.2 & NS \\
\hline \multicolumn{4}{|c|}{ Weed control practices } \\
\hline Pendi fb 1HW(30DAS) & $5.4(29.0)$ & $6.3(39.8)$ & 82.2 \\
\hline Bispyri fb 1HW(45DAS) & $4.0(15.6)$ & $5.5(30.7)$ & 86.2 \\
\hline $\begin{array}{l}\text { Pendi fb Bispyri fb } 1 \mathrm{HW} \\
\text { (45DAS) }\end{array}$ & $3.0(8.6)$ & $5.0(24.7)$ & 87.4 \\
\hline Weedy check & $10.4(108.8)$ & $12.8(164.3)$ & 0 \\
\hline SEm \pm & 0.08 & 0.1 & 2.2 \\
\hline C.D. at $5 \%$ & 0.2 & 0.3 & 6.4 \\
\hline
\end{tabular}

Original values are given in parenthesis; Pendi: Pendimethalin, Bispyri: Bispyribac Na, HW: Hand weeding.

ment combinations were significantly (5\%) superior to the weedy check and wider spacing $(25 \times 25 \mathrm{~cm})$ was significantly $(5 \%)$ superior than other spacings with respect to yield attributes viz. panicles $\mathrm{m}^{-2}$, no. of grains panicles $^{-1}$ (Table 1). Among the treatments, continuous drilling at $20 \mathrm{~cm}$ and Pendimethalin $(1 \mathrm{~kg}$ a. i. $\left.\mathrm{ha}^{-1}\right)+$ bispyribac-Na $\left(25 \mathrm{~g}\right.$ a.i. $\left.\mathrm{ha}^{-1}\right)+$ one hand weeding at 45 days after sowing recorded the lowest weed count and dry weight (Table 2) and the highest number of panicles $\mathrm{m}^{-2}$, grains panicle ${ }^{-1}$ and grain yield (Table 1). This might be due to efficient hand weeding which restrict the growth of weeds in the field of aerobic rice. Singh et al. (2006) reported that both pre-emergence and post-emergence herbicides can be used in aerobic rice fields along with hand weeding and they effectively control the weeds, if properly used.

The weed control measures resulted in higher $\mathrm{N}$ uptake by crops and helped in realizing higher grain yield of rice (Jacob and Syriac, 2005). Among the herbicidal treatments, maximum grain yield and favourable yield attributes were obtained with the application of pendimethalin $\left(1 \mathrm{~kg} \mathrm{a.} \mathrm{i.} \mathrm{ha}{ }^{-1}\right)+$ bispyribac-Na $\left(25 \mathrm{~g}\right.$ a. i. ha $\left.{ }^{-1}\right)$ + one hand weeding at 45 DAS and recorded an increase of $82.1 \%$ yield over weedy check and significantly $(5 \%)$ superior than other weed control treatments while among planting geometry, continuous drilling at $20 \mathrm{~cm}$ recorded an increase of $16.5 \%$ yield over wider $(25 \times 25 \mathrm{~cm})$ spacing. Narrow row spacing 
can shift the competitive balance in favour of rice by achieving faster canopy closure and reducing light availability to weeds (Chauhan and Johnson, 2010 ). This increase in yield could be due to lower weed count that resulted in efficient utilization of available resources by the crop (Sundari and Kathiresan, 2002).

All the weed control treatments registered a significant reduction in total weed population and total weed dry matter compared with the weedy check throughout the crop growth (Table 2). It was further observed that among spacings, continuous drilling at $20 \mathrm{~cm}$ and among weed control treatments, Pendimethalin $(1 \mathrm{~kg}$ a. i. ha $\left.^{-1}\right)+$ bispyribac-Na $\left(25 \mathrm{~g}\right.$ a. i. ha $\left.{ }^{-1}\right)+$ one hand weeding at 45 days after sowing reduced total weed density and weed dry matter significantly $(5 \%)$ by $17.8,15.7 \%$ and $73.3,75.7 \%$, respectively, compared to weedy check.

It was also found that the highest $\mathrm{N}$-use efficiency was recorded under continuous drilling at $20 \mathrm{~cm}$, among the planting geometry and Pendimethalin $\left(1 \mathrm{~kg}\right.$ a. i. ha $\left.{ }^{-1}\right)+$ bispyribac-Na $\left(25 \mathrm{~g}\right.$ a. i. ha $\left.{ }^{-1}\right)+$ one hand weeding at 45 days after sowing, among weed control practices. Crop also exhibited improvement in $\mathrm{N}$ uptake with the adoption of combined weed control measures and spacing. Lowest $\mathrm{N}$ uptake was under weedy conditions. The $\mathrm{N}$ uptake by weeds followed the reverse trend. Effective combined weed control measures reduced the weed biomass which in turn reduced weed competition and there by resulted in the improvement of $\mathrm{N}$ uptake by crop (Bali et al., 2006). Crop yield and weed control efficiency were positively correlated. One percent increase in weed control efficiency caused increase in grain yield by $38 \mathrm{~kg}$. This increase in grain yield by increasing weed control efficiency (WCE) was also reported by Singh and Singh (2006). However, the uptake of nitrogen was negatively correlated with grain yield. Regression analysis $(y=5790-188.1 x)$ also indicated that one $\mathrm{kg}$ increase in $\mathrm{N}$ uptake by weeds causes reduction in grain yield by $188.1 \mathrm{~kg} \mathrm{ha}^{-1}$. The competitive effect of weeds for nutrient was also reported by Bali et al. (2006) for direct seeded rice .

The maximum net returns and benefit:cost ratio was obtained with continuous drilling at $20 \mathrm{~cm}$ with pendimethalin $\left(1 \mathrm{~kg}\right.$ a. i. ha $\left.{ }^{-1}\right), 3$ days after sowing+ bispyribac-Na (25g a. i. ha $\left.{ }^{-1}\right), 28$ days after sowing +1 hand weeding at 45 days after sowing (Table 1). The corresponding values being ₹ 40576 and 1.7 and ₹ 40633 and 1.8 , which are very much higher than weedy condition. This might be due to application of pre emergence herbicide $\mathrm{fb}$ post emergence herbicide application along with one hand weeding (45 DAS) due to inhibition of weed dry weight as well as reduced crop weed competition which ultimately increased the grain yield. Bhurer et al. (2013) reported that the use of preemergence herbicide $f \mathrm{~b}$ post-emergence along with one hand weeding in rice crop produced maximum crop dry matter accumulation and increase the crop yield.

\section{Conclusion}

Combination of planting geometry and different weed control measures i.e. continuous drilling at $20 \mathrm{~cm}$ with pendimethalin $\left(1 \mathrm{~kg}\right.$ a. i. ha $\left.{ }^{-1}\right), 3$ days after sowing+ bispyribac-Na (25g a. i. ha ${ }^{-1}$ ), 28 days after sowing +1 hand weeding at 45 days after sowing proved to be effective and a profitable alternative to the existing recommendation of alone application of herbicide with hand weeding in direct seeded rice.

\section{REFERENCES}

Bali, S.A., Singh, M., Kachroo, D., Sharma, B.C. and Shivram, D.R. (2006). Efficacy of herbicides in transplanted, medium-duration rice (Oryza sativa) under sub -tropical conditions of Jammu. Indian J Agronomy, 51 (2): $128-130$

Bhurer, K.P., Yadav, D.N., Ladha, J.K., Thapa, R.B. and Pandey, K. (2013). Effect of integrated weed management practices on performance of dry direct seeded rice (Oryza sativa L.), Agronomy J. of Nepal, 3 :53-63

Black, C.A. (1965). Methods of soil analysis Part 2. American Society of Agronomy, Madison Wisconsin, U.S.A. pp. 1372-1376

Chauhan, B.S. and Johnson, D.E. (2010). Relative importance of shoot and root competition in dry seeded rice growing with jungle rice and Ludwigia. Weed science, 58: 295-299

Jackson, M.L. (1973). Soil chemical analysis prantice hall pvt. Itd., New Delhi, India. pp. 498

Jacob, D. and Syriac, E.K. (2005). Relative efficiency of different spacing and weed control methods in scented rice. Oryza, 42 (1): 75-77

Khaliq, A. and A. Matloob. (2011). Weed crop competition period in three fine rice cultivars under direct seeded rice culture. Pakistan J. Weed Sci. Res., 17(3): 229-243

Olsen, S.R., Cole, C.V. and Dean, L.A. (1954). Estimation of available phosphorus in soil by extraction sodium bicarbonate. In: Black, C.A. (ed.) method of soil analysis, Part 2. American Society of Agro. Inc. Madison, USA, pp: 1044-1046

Rao, A.N., Johnson, D.E., Sivaprasad, B., Ladha, J.K. and Mortimer, A.M. (2007). Weed management in directseeded rice. Adv. Agron., 93: 153-255

Singh, P. and Singh, S.S. (2006). Effect of establishment methods, fertility levels and weed-management practice in aromatic rice (Oryza sativa). Indian J. Agronomy, 51 (4): $247-250$

Singh, U.P., Singh, R.P. and Singh, Y. (2006). Integrated weed management in direct dry seeded rainfed lowland rice. Indian J. of Weed Sci., 38 (1\&2): 49.

Subbiah, B.V. and Asija, I.A. (1956). A rapid procedure for the determination of available nitrogen in soil. Current Sci., 25, 259-260

Sundari, A. and Kathiresan, R.M. (2002). Integrated weed management in irrigated Sorghum. Indian J. Weed Sci., 34 (3\&4): 313-315 